\title{
Implementasi Pemikiran Imam Al-Ghazali tentang Pendidikan Karakter
}

\author{
Andika Dirsa ${ }^{1}$ dan Intan Kusumawati ${ }^{2}$ \\ ${ }^{1}$ Ilmu Pengetahuan Sosial, Universitas Negeri Yogyakarta \\ ${ }^{2}$ Ilmu Pendidikan, Universitas Negeri Yogyakarta. \\ Jl. Colombo No.1, Karang Malang, Caturtunggal, Kecamatan Depok, \\ Kabupaten Sleman, Daerah Istimewa Yogyakarta 55281 \\ ${ }^{1}$ Email: andika1365pasca2015@student.uny.ac.id \\ ${ }^{2}$ Email: intan.kusumawati2016@student.uny.ac.id
}

\begin{abstract}
ABSTRAK
Tujuan penelitian ini untuk mengetahui implementasi pelaksanaan pendidikan karakter pada anak usia dini. Pendidikan karakter merupakan suatu proses yang berkelanjutan, tujuan yang akan dicapai oleh pendidikan karakter adalah implementasi dari nilai-nilai teladan yang terbentuk dalam setiap pribadi manusia sebagai mahkluk sosial. Tujuan pendidikan karakter yang diinginkan oleh Imam Al-Ghazali adalah taqarrub ilallah dan kesempurnaan untuk mencapai kebahagiaan hidup dunia dan akhirat. Pemikiran Imam Al-Ghazali tentang pendidikan karakter selalu menampilkan sisi moralitas dan spiritualitas. Hasil yang dicapai dalam penelitian ini bahwa implementasi pendidikan karakter pada anak usia dini yang menurut Imam Al-Ghazali merupakan pemikiran yang mendasarkan pada pembiasaan yang dimulai dari memberikan contoh dan latihan-latihan, agar terbentuk akhlak yang baik sebagai dasar pembentukan karakter manusia yang bermartabat.
\end{abstract}

Kata Kunci: Pendidikan Karakter; Imam Ghazali.

\begin{abstract}
The purpose of this study was to determine the implementation of character education in early childhood. Character education is an ongoing process, the goal to be achieved by character education is the implementation of the exemplary values formed in each human person as a social being. The purpose of character education desired by Imam Al-Ghazali is taqarrub ilallah and perfection to achieve happiness in the life of the world and the hereafter. Imam Al-Ghazali's thoughts on character education always show the morality and spirituality side. The results achieved in this study that the implementation of character education in early childhood which according to Imam Al-Ghazali is a thought that is based on habituation that starts from giving examples and exercises, in order to form good morals as a basis for the formation of dignified human character.
\end{abstract}

Keywords: Character Education; Imam Ghazali.

\section{PENDAHULUAN}

Problematika yang dihadapi dunia pendidikan saat ini adalah degradasi moral dan kurangnya akhlak atau degradasi moral pada remaja. Berbagai tindakan kriminal sering dijumpai dalam berbagai media massa seperti tayangan televisi, koran, atau surat kabar lainnya. Kasus tindak pidana korupsi, kolusi dan nepotisme marak terjadi, mulai dari bidang baik pemerintahan maupun swasta. Bahkan dalam bidang pendidikan, seperti mencontek pada waktu ujian dan melakukan plagiarisme merupakan bentuk praktikpraktik kebohongan yang terjadi di dunia pendidikan. Permasalahan yang muncul ini tidak terlepas dari karakter anak bangsa yang mulai mengalami penurunan. 
Realita yang ada saat ini menunjukkan bahwa pendidikan karakter sangat perlu diterapkan. Agar terbentuk karakter yang benar, harus melalui proses pembinaan, sebab tanpa pembinaan karakter ibarat berjalan dalam gelap tanpa cahaya. Pendidikan karakter esensinya adalah sebuah upaya membangun kecerdasan manusia, baik kecerdasan kognitif (pengetahuan), afektif (sikap) dan psikomotorik (keterampilan). Oleh sebab itu, pendidikan karakter harus digaungkan secara terus-menerus supaya menghasilkan generasi yang cerdas, unggul dan memiliki karakter yang tangguh. Hal ini sejalan dengan filosofi Pancasila yang menginginkan manusia Indonesia yang ideal, menghargai nilai-nilai ketuhanan, kemanusiaan, persatuan, kerakyatan, dan keadilan sosial.

Pendidikan karakter harus direalisasikan dalam ruang sekolah, sekolah perlu menginternalisasikan nilai-nilai karakter yang penting kedalam setiap anak didik dan lulusannya. Sebagaimana Lickona (1991) menyebutkan bahwa nilai yang dianggap penting untuk dikembangkan menjadi karakter ada dua, yaitu respect (hormat) dan responsibility (tanggung jawab). Lickona menganggap penting kedua nilai ini untuk pembangunan kesehatan pribadi seseorang, menjaga hubungan interpersonal sebuah masyarakat yang manusiawi dalam suasana demokratis, dunia yang lebih adil dan damai. Adapun pendidikan karakter merupakan suatu sistem penanaman nilai-nilai karakter kepada warga sekolah yang meliputi komponen pengetahuan, kesadaran atau kemauan, dan tindakan untuk nilai-nilai tersebut. Pendidikan karakter pada hakekatnya ingin membentuk individu menjadi seorang pribadi bermoral yang dapat menghayati kebebasan dan tanggung jawabnya, dalam relasinya dengan orang lain dan dunianya dalam komunitas pendidikan (Fihris, 2010).

Pendidikan karakter yang dilaksanakan semestinya dimulai penanamannya dari anak usia dini, di mana masa itu merupakan masa-masa emas pembentukan karakter anak. Pendidikan moral anak usia dini (Kusumawati, 2019) melalui pendekatan konstruktivis berfokus pada pelaksanaan praktik keseharian yang sesuai dengan perkembangan anak sejak lahir. Melalui pendekatan konstruktivis maka tujuan dari penelitian ini adalah mengetahui perkembangan anak dalam semua bidang kurikulum dan semua domain perkembangan berkembang, baik fisik ataupun moralnya. Tujuan pendidikan moral anak usia dini melalui pendekatan konstruktivis agar kelak anak menjadi pelajar yang mandiri. Peran guru (Kusumawati, 2017) menjadi penting pembelajaran karakter berbasis pendidikan agama Islam. Ia harus konsisten dalam pembelajaran yang berorientasi kebutuhan anak dan siswa Raudlatul Athfal. Di sini dapat disimpulkan bahwa pendidikan karakter akan menjadi sebuah pondasi yang kuat ketika penanaman pendidikan karakter 
dimulai sejak dini. Pembentukan tingkah laku dan karakter seseorang (Amini, 2010) dimulai sejak ia lahir, berjalan seiring dengan perkembangan dan penyesuaiannya terhadap lingkungan sosial.

Banyak ahli yang telah mengkaji pendidikaan karakter, salah satunya adalah Imam Al-Ghazali, seorang filsuf Islam yang banyak melahirkan karya-karya fenomenal dan menjadi rujukan sampai saat ini. Pemikiran Al-Ghazali tidak hanya terbatas pada aspek ilmu keagamaan saja, beliau juga populer dengan pemikiran-pemikirannya dalam aspek pendidikan karakter. Sampai saat ini pengaruh pemikiran Al-Ghazali tentang karakter masih eksis dan menjadi rujukan kampus-kampus, forum ilmiah kajian karakter, terutama kaum muslim didunia. Bahkan, Ignaz Goldziher (Baharuddin, 2011) mengakui bahwa sosok Al-Ghazali telah memberikan effect dan impact yang begitu besar baik dalam historisitas pemikiran Islam maupun pada religuisitas kaum muslimin. Al-Ghazali tidak hanya dikenal sebagai seorang teolog dan mistikus, tetapi dia juga menguasai bidang yurisprudensi (hukum), etika, logika, bahkan kajian filsafat. Dia dinilai sebagai seorang ilmuan Islam yang ensiklopedis dengan menguasai hampir seluruh khazanah-khazanah keilmuan dari berbagai disiplin yang sangat berbeda. Kemampuannya mengelaborasi serta mengepresikan gagasan-gagasan pemikiran pada setiap karya-karyanya, dinilai sangat orisinil, kritis, bahkan komunikatif. Dengan demikian, dalam artikel ini bertujuan untuk mendeskripsikan implementasi pendidikan karakter dalam perspektif Imam Al-Ghazali, case study pada Tempat Penitipan Anak (TPA) Taman Bocah Permata Hati.

\section{METODE PENELITIAN}

Metode yang dilakukan dalam penelitian ini adalah penelitian kualitatif. Penelitian kualitatif ini sebuah metode penelitian yang sifatnya menceritakan atau mendeskripsikan dengan menggunakan analisis, mengacu pada data yang ada dalam penelitian, memanfaatkan teori sebagai bahan pendukung, serta menghasilkan suatu teori. Menurut Sugiyono (2009:15) metode penelitian kualitatif adalah penelitian yang digunakan untuk menyelidiki, menemukan, menggambarkan, dan menjelaskan kualitas atau keistimewaan dari pengaruh sosial yang tidak dapat dijelaskan, diukur atau digambarkan melalui pendekatan kuantitatif. Subyek penelitian ini adalah siswa anak usia dini, guru serta orangtua wali siswa dan masyarakat yang ada di Taman Penitipan Anak Taman Permata Hati. Penelitian ini dilakukan di Taman Penitipan Anak (TPA) Taman Bocah Permata Hati. TPA Taman Bocah Permata Hati berlokasi di Dukuh Banyuraden Kecamatan Gamping Sleman Provinsi Daerah Istimewa Yogyakarta. 


\section{HASIL DAN PEMBAHASAN}

\section{Implementasi Pendidikan Karakter Anak Usia Dini dalam Perspektif Al-Ghazali}

Pendidikan karakter yang kemudian menjadi character education adalah tema sentral dan jamak dikaji saat ini. Secara terminologi, Al-Ghazali mendefinisikan pendidikan karakter dengan istilah akhlak dan membaginya menjadi akhlak yang baik (al khuluq al hasan) dan akhlak yang buruk (al khuluq as sayyi). Lebih lanjut, ia mengatakan akhlak mengalami perubahan, artinya akhlak dapat diperoleh melalui proses belajar dan dapat pula diubah melalui proses belajar, dengan cara mendorong jiwa untuk melakukan perbuatan-perbuatan yang dituntut oleh akhlak yang dimaksud.

Dalam kitab Ihya 'Ulum al-Din, Al-Ghazali (Hanani 2014) membagi beberapa konsep pendidikan karakter, di antaranya:

a. Orientasi Pendidikan Karakter

Pendidikan karakter lebih diorientasikan untuk mendekatkan diri kepada Allah SWT dan memperoleh kebahagiaan di dunia dan akhirat. Sebagaimana pernyataannya "Pangkal kebahagiaan di dunia dan akhirat adalah ilmu. Jika demikian ilmu adalah seutama-utama amal. Bagaimana tidak, sedangkan kamu mengetahui juga bahwa keutamaan sesuatu itu dengan kemuliaan buahnya. Dan kamu mengetahui bahwa buah ilmu adalah dekat kepada Allah, Tuhan semesta alam”.

b. Sasaran Pengembangan dalam Pendidikan Karakter

Dalam pendidikan Islam, hendaknya mampu mengembangkan karakter seperti berpikir, membaca Al-Qur'an, merenung, muhasabah, mengingat kematian, keikhlasan, kesabaran, syukur, ketakutan dan harapan, kemurahan hati, kejujuran, cinta, dan lainlain sebagainya. Karakter yang dikembangkan bagi anak didik dalam kitab Ihya 'Ulum al-Din. Diantaranya: 1) Mengutamakan penyucian jiwa dan ibadah. 2) Tawakal. 3) Karakter ikhlas. 4) Solidaritas. 5) Cinta ilmu bermanfaat. 6) Jujur. 7) Kesederhanaan. 8) Sabar. 9) Syukur. 10) Sikap lemah lembut.

Al-Ghazali mengemukakan metode mendidik anak dengan memberi contoh-contoh, latihan-latihan dan pembiasaan kemudian nasihat dan anjuran sebagai instrumen pendidikan dalam rangka membina kepribadian anak sesuai dengan ajaran agama Islam. Pembentukan kepribadian itu berlangsung secara berangsur-angsur dan berkembang sehingga merupakan proses menuju kesempurnaan. Al-Ghazali (Ihsan dan Ihsan, 2001) mengatakan:

Apabila anak dibiasakan untuk mengamalkan segala sesuatu yang baik, diberi $\underline{\text { pendidikan ke arah yang baik maka, pastilah ia akan tumbuh di atas kebaikan dan akibat }}$ 
positifnya ia akan selamat sentosa di dunia dan akhirat. Kedua orang tuanya dan semua pendidik, pengajar serta pengasuhnya ikut serta memperoleh pahalanya. Sebaliknya, jika sejak kecil sudah dibiasakan mengerjakan keburukan dan dibiarkan begitu saja tanpa dihiraukan pendidikan dan pengajarannya sebagaimana halnya seorang yang memelihara binatang, maka akibatnya anak itu pun akan celaka dan rusak binasa akhlaknya, sedangkan dosanya yang utama tentulah dipikulkan oleh orang (orang tua, pendidik) yang bertanggung jawab untuk memelihara dan mengasuhnya.

Implementasi pendidikan karakter pada anak usia dini di TPA Taman Bocah Permata Hati sangat tampak ketika pendidikan karakter yang diterapkan. Pelaksanaan pendidikan karakter, sesuai dengan pemikiran Al- Ghazali menganjurkan untuk mendidik anak dan membina akhlaknya dengan latihan-latihan dan pembiasaan-pembiasaan yang sesuai dengan perkembangan jiwanya walaupun seakan-akan dipaksakan, hal ini berguna agar anak dapat terhindar dari perbuatan yang menyesatkan. Latihan dan pembiasaan tersebut akan membentuk sikap tertentu pada anak, yang lambat laun sikap itu akan bertambah jelas dan kuat, sehingga tidak tergoyahkan lagi karena telah masuk menjadi bagian dari kepribadiannya. Kemudian. ia mengatakan jikalau anak itu sejak tumbuhnya sudah dibiasakan dan diajari yang baik-baik, maka nantinya setelah ia mencapai usia hampir balig, tentulah ia akan dapat mengetahui rahasianya, yakni mengapa perbuatanperbuatan yang tidak baik itu dilarang oleh orang tuanya. Sesuai dengan hasil wawancara kepada guru atau pendamping TPA Taman Bocah Permata Hati yang dilakukan pada hari Senin, 11 Maret 2019, sebagai berikut:

"Dalam mendidik dan mendampingi anak, diperlukan perhatian yang serius dalam membentuk dan menjadikan anak memiliki pondasi yang kuat lewat sebuah pembiasaan yang baik dan rutinitas, misalnya pembiasaan berbicara sopan kepada teman dan kepada guru, menghormati oranglain, bersikap jujur, disiplin dan berani mengakui kesalahan merupakan pembiasaan baik yang perlu dibina sejak dini." Pembiasaan ini dimaksudkan agar dimensi-dimensi jasmaniah dari kepribadian individu (anak) dapat terbentuk dengan memberikan kecakapan berbuat dan berbicara. Tahap pembiasaan ini menjadi penopang dan persiapan yang mendasar untuk kehidupan dan perkembangan kepribadian anak di masa mendatang. Pengalaman yang diperoleh pada tahap pembiasaan akan bermanfaat untuk mendasari proses lebih lanjut. Menurut Imam AlGhazali bahwasanya suatu ajaran yang akan membuahkan hasil membutuhkan latihanlatihan dan pembiasaan yang panjang proses waktunya dan perhatian guru atau dari pendidik yang konstan. 
Al-Ghazali (Ihsan \& Ihsan, 2001) memberikan pandangannya tentang pendidikan akhlak susila bagi anak sebagai berikut:

\section{Kesopanan}

Kesopanan mengandung nilai-nilai pendidikan karakter, seperti:

a. Pada saat anak makan bersama keluarga akan tertanam rasa persatuan antara keluarga dan rasa hormat kepada orang yang lebih dewasa.

b. Anak dilatih menghargai milik orang lain sebagaimana orang lain menghargai miliknya serta sebagai latihan bekerja sama dengan orang lain.

c. Anak dapat makan sendiri sehingga memberikan rasa kepercayaan kepada diri sendiri.

d. Orang tua dapat menghormati bagaimana sikap anak pada saat makan.

Pendidikan karakter anak (character building) semestinya dijalankan dalam lingkungan keluarga, karena keluarga adalah awal pembentukan karakter pada anak usia dini. pendidikan anak usia dini bisa dimulai dalam lingkungan keluarga. Hal ini sejalan dengan amanat Undang-undang nomor 20 tahun 2003 tentang Sistem Pendidikan Nasional, yang menegaskan bahwa setiap anak berhak mendapatkan pendidikan untuk mengembangkan pribadi dan kecerdasannya sesuai minat dan bakatnya. Pada saat wawancara dengan salah satu orangtua murid, yang mengatakan:

"Kita mendidik anak dirumah dengan membiasakan makan dengan tangan kanan dan makan serta minum dalam posisi duduk, kegiatan pembiasaan yang dilakukan dirumah ini untuk menanamkan tata cara adab makan dan minum yang baik kepada anak".

Seorang anak haruslah memiliki sikap sopan dan santun kepada semua orang, terlebih kepada orangtua dan gurunya. Karena ini merupakan karakter yang penting dan harus dilakukan, sebab adab adalah hal yang terpenting dilingkungan keluarga dan sekolah. Pendidikan karakter anak usia dini haruslah memperhatikan sisi emosionalnya. Sudaryanti (2012), menjelaskan "Dampak adanya pendidikan karakter pada anak usia dini akan menimbulkan kematangan emosinya. Kecerdasan emosi merupakan bekal yang terpenting bagi si anak dalam menyongsong masa depannya dengan penuh rintangan dan hambatan baik dalam segi akademis maupun terhadap kehidupan berbangsa dan bernegara secara umum".

Ketika pendidikan karakter sudah tertanam pada si anak, pasti akan mendatangkan suasana yang damai dan penuh kasih sayang. Pendidikan karakter ditanamkan kepada anak usia dini sangat penting untuk menjaga agar si anak senantiasa berada pada jalur yang 
benar sesuai ajaran agama yang menghendaki adanya kehidupan yang aman dan penuh kedamaian.

\section{Kedisiplinan}

Al-Ghazali sangat mengutamakan kedisiplinan anak untuk menghindarkan perbuatan yang tidak pantas dipandang umum dan membiasakan anak untuk berbuat hal-hal yang sesuai dengan norma-norma masyarakat yang berlaku. Ia mengatakan:

"Ayah hendaknya mengajarkan anaknya tentang bagaimana cara duduk yang baik, hendaklah dilarang meletakkan salah satu kaki diatas kaki yang lainnya, demikian pula meletakkan tangan di bawah dagu dan menyandarkan kepala di atas tangan (topang dagu), sebab semuanya ini adalah tanda pemalas.”

Disamping mengajarkan sopan santun dan disiplin pada waktu duduk, juga sekaligus menghindarkan sikap malas yang ada pada anak, agar anak terlatih kreatif, rajin belajar dan giat bekerja. Sebelum anak dapat berpikir logis dan memahami hal-hal yang abstrak, serta belum sanggup memilah mana yang baik dan mana yang buruk, mana yang benar dan yang salah, maka contoh-contoh, latihan-latihan dan pembiasaanpembiasaan (habit forming) mempunyai peranan yang sangat penting, dalam pembinaan pribadi anak, karena sebelum dewasa adalah masa paling baik untuk menanamkan dasar-dasar pendidikan akhlak atau karakter.

Pandangan pendidikan Al-Ghazali dalam pendidikan karakter yaitu akhlak susila seperti yang dilaksanakan anak usia dini di TPA Taman Bocah Permata Hati, sesuai dengan hasil wawancara kepada guru atau pendamping TPA Taman Bocah Permata Hati yang dilakukan pada hari Senin, 11 Maret 2019, sebagai berikut:

"Kegiatan sehari hari yang dilakukan anak usia dini di TPA Taman Bocah Permata Hati adalah dengan pembiasaan pada saat makan dengan dimulai dengan berdoa sebelum makan dan sesudah makan. Anak dilatih makan dan minum sendiri secara mandiri. Berbagi makanan kepada teman ketika teman tidak membawa bekal makan. Semua itu dilakukan agar anak terbiasa melakukan kegiatan yang baik dan sesuai dengan ajaran agama Islam. Kegiatan pembiasaan ini bisa diajarkan kepada anak melalui contoh dan latihan serta suri tauladan dari orang tua, orang dewasa di sekitar anak tersebut berada serta guru atau pendamping dan juga masyarakat ikut berperan aktif dalam pembentukan karakter anak."

Implementasi pendidikan yang dilakukan anak usia dini di TPA Taman Bocah

Permata Hati sesuai dengan pemikiran Al-Ghazali dalam pendidikan karakter lewat suatu kebiasaan yang baik dan dilakukan dengan baik. Melalui pendidikan tentang kedisiplinan dan juga tentang kesopanan menjadikan anak terpola pondasi karakternya. Pada hakikatnya pendidikan haruslah dimulai sedini mungkin, termasuk dalam hal penegakan disiplin. Mendidik anak tidak boleh ada unsur paksaan, dibutuhkan 
kesabaran bagi seorang pendidik atau orangtua dalam mendidik anaknya. Disiplin itu membutuhkan kesadaran untuk melakukan sesuatu hal. Kesadaran seorang anak akan disiplin adalah buah kesabaran orangtua atau guru dalam bersikap dan mengayomi si anak. Melalui disiplin anak diajarkan bagaimana berperilaku sesuai norma-norma atau standar sosial dalam kehidupan bermasyarakat dan bernegara. Oleh karena itu, penanaman disiplin yang tepat akan sangat diperlukan untuk membentuk karkater yang baik dan positif bagi si anak.

\section{Relevansi pemikiran pendidikan karakter Al-Ghazali terhadap pendidikan di}

\section{Indonesia}

Ketika berbicara tentang pendidikan karakter, bukan berarti berbicara bagaimana ajaran yang benar dan yang salah. Lebih daripada itu, pendidikan karakter haruslah menanamkan kebiasaan (habituasi) tentang hal mana yang baik dan benar untuk dilakukan sehingga anak didik menjadi paham (kognitif) tentang mana yang benar dan salah, mampu merasakan (afektif) nilai yang baik dan biasa melakukannya (psikomotor).Dengan kata lain, pendidikan karakter yang baik harus melibatkan aspek pengetahuan yang baik (moral knowing), merasakan yang baik atau loving good (moral feeling) dan perilaku yang baik (moral action). Artinya pendidikan karakter haruslah menekankan pada kebiasaan atau habit yang dilakukan secara terus-menerus untuk di implementasikan dalam sekolah dan kehidupan sehari-hari. Pendidikan karakter (Farida, 2016) dimaknai sebagai pendidikan nilai, budi pekerti, pendidikan moral, pendidikan watak yang tujuannya untuk mengembangkan kemampuan peserta didik untuk memberikan keputusan baik buruk, mewujudkan kebaikan dalam kehidupan sehari-hari dengan sepenuh hati sebagai cita-cita luhur dalam dunia pendidikan.

Menurut Undang-undang Sistem Pendidikan Nasional (Sisdiknas) Nomor 20 tahun 2003 menyebutkan bahwa tujuan pendidikan nasional adalah :

"Berkembangnya potensi peserta didik agar menjadi manusia yang beriman dan bertakwa kepada Tuhan Yang Maha Esa, berakhlak mulia, sehat, berilmu, cakap, kreatif, mandiri, dan menjadi warga negara yang demokratis serta bertanggung jawab".

Makna yang terkandung dalam Undang-undang tersebut tentang tujuan pendidikan nasional di Indonesia, menegaskan bahwa tujuan dari pendidikan nasional di Indonesia adalah merupakan satu kesatuan yang utuh dan saling terkait antara satu dengan yang lain. Esensinya adalah membentuk manusia Indonesia seutuhnya, dengan kata kunci adalah beriman dan bertakwa. 
Pandangan yang sama juga dipaparkaan oleh Al-Ghazali dalam Risalah Ayyuha alWalad mengenai prinsip pendidikan karakter yaitu menekankan pada pentingnya nilai akhlak yang mengarah pada prinsip integrasi spiritualitas dalam tujuan pendidikan karakter. Ia menganggap bahwa karakter lebih dekat dengan akhlaq, yaitu spontanitas manusia dalam bersikap, atau melakukan perbuatan yang telah menyatu dalam diri manusia sehingga ketika muncul tidak perlu dipikirkan lagi. Apa yang dikatakan AlGhazali tersebut merupakan karakter yang telah mengakar dalam diri seseorang. Dimana nilai-nilai yang sebelumnya menjadi acuan telah dipahami dengan benar dan diaplikasikan dalam kehidupan bermasyarakat. Karakter bersumber dari nilai-nilai luhur yang secara moral membentuk pribadi seseorang dan tercermin dalam perilaku (Setiawan, 2014: 9). Hal ini sejalan dengan yang diungkapkan oleh Ki Hajar Dewantara adalah "ngertingerasa-ngelakoni" (mengerti, merasakan, melakukan). Maksud tersebut mengandung pengertian bahwa pendidikan karakter adalah bentuk pendidikan dan pengajaran yang menitikberatkan pada perilaku dan tindakan siswa dalam mengapresiasikan dan mengimplementasikan nilai-nilai karakter ke dalam tingkah lakunya sehari-hari (Tilaar, 1999:130).

Pendidikan karakter merupakan langkah penting dan strategis dalam membangun kembali jati diri individu maupun bangsa. Tetapi penting untuk segera dikemukakan bahwa pendidikan karakter haruslah melibatkan semua pihak, rumah tangga dan keluarga, sekolah, dan lingkungan sekolah lebih luas atau masyarakat. Karena itu, langkah pertama yang harus dilakukan adalah menyambung kembali hubungan dan educational network yang nyaris terputus antara ketiga lingkungan pendidikan ini. Pendidikan karakter (Kosim, 2012) adalah upaya terencana dalam membantu seseorang untuk memahami, peduli, dan bertindak berdasarkan nilai-nilai etika

Kesuksesan dalam mewujudkan pendidikan karakter di sekolah sangat erat kaitannya dengan sosok guru karena guru merupakan faktor penting yang berpengaruh, bahkan dapat dikatakansebagai penentu berhasil tidaknya sebuah proses pendidikan karakter di sekolah. Guru sebagai pengganti peran orangtua di sekolah merupakan sosok yang digugu dan ditiru oleh para siswanya. Mengingat bahwa pendidikan karakter menekankan pada aspek pembentukan sikap, nilai, dan watak peserta didik, maka dalam pembentukkannya harus dimulai dari para gurunya (Mulyasa, 2013: 31). Guru harus memiliki pemahaman yang mendalam terkait karakter atau kepribadian anak didiknya. Ia harus sanggup mengayomi semua anak didiknya dari yang masih muda (anak-anak hingga yang sudah dewasa. Hal ini penting dilakukan sembari memahami dari masing-masing 
karakteristik anak didiknya. Ketika seorang guru tidak mampu memberikan teladan dan memahami karakteristik dari masing-masing anak didiknya, maka ia telah gagal alias tidak berhasil mengajar dan mendidik.

Implikasi dari pemikiran Al-Ghazali terhadap pendidikan pada masa sekarang tentu perlu penambahan dan penyempurnaan serta modifikasi agar sesuai dengan perkembangan teknologi pendidikan dan sistem pendidikan sekarang. Oleh sebab itu, pendidikan karakter senantiasa mengarahkan diri pada pembentukan individu yang bermoral, berpengetahuan luas, cakap mengambil keputusan, sekaligus mampu berperan aktif dalam membangun kehidupan bersama, baik di lingkungan rumah, sekolah dan bahkan di dalam kehidupan bermasyarakat, berbangsa dan bernegara. Pendidikan anak (Janna, 2013) merupakan sesuatu yang urgen untuk diperhatikan. Karena anak terlahir dengan memiliki potensi yang perlu untuk ditumbuhkembangkan. Selain itu anakmerupakan bagian terpenting dari seluruh proses pertumbuhan manusia.Adapun implikasinya terhadap Pendidikan di anak usia dini hendaknya pendidikan selalu disesuaikan berdasarkan usia perkembangan anak. Jadi, indikator dari pemikiran al-Ghazali tentang akhlak adalah suatu sifat yang meresap dalam kehidupan sehari-hari.

\section{KESIMPULAN}

Mendidik anak sejak anak usia dini melalui latihan dan contoh-contoh melalui suri tauladan merupakan langkah yang bagus dan bijaksana. Lewat penanaman karakter sejak dini akan menjadikan anak menjadi pribadi yang tumbuh secara baik dan memiliki nilainilai karakter yang kelak akan diterapkannya dalam kehidupannya sehari-hari mulai dari lingkungan keluarga, sekolah dan ketika anak nanti tumbuh remaja dan menjadi dewasa berada di tengah-tengah kehidupan masyarakat. Pendidikan karakter yang baik adalah pendidikan yang dibiasakan dari kecil atau dibiasakan sejak dini agar terbentuklah karakter yang baik. Penanaman karakter sejak dini bagi si anak akan memiliki dampak yang positif bagi perkembangan moral anak untuk mencapai kebahagiaan dalam hidupnya.

\section{SARAN}

Penelitian tentang pendidikan karakter yang dilakukan di anak usia dini semestinya bisa menjadi rujukan untuk penelitian pendidikan karakter di tingkat berikutnya. Penelitian di Taman Kanak-kanak (TK), Sekolah Menengah Pertama (SMP), Sekolah Menengah Atas (SMA) dan tingkat perguruan tinggi (PT). 


\section{DAFTAR PUSTAKA}

Abu Hamid Muhammad bin Muhammad Al-Ghazali. (2007). Ihya 'Ulum al-Din, Darussalam, Kairo Mesir, Jilid I.

Amini, M. (2010). Peran Pengasuhan Guru Pada Pembentukan Karakter Anak Sejak Dini. In: Teтu Ilmiah Nasional Guru II: Membangun Profesionalitas Insan Pendidikan Yang Berkarakter dan Berbasis Budaya, 24-25 November 2010, Tangerang Selatan.

Farida, S. (2016). Pendidikan karakter dalam prespektif islam. KABILAH: Journal of Social Community, 1(1), 198-207.

Fihris. (2010). Pendidikan Karakter di Madrasah Salafiyah. Semarang: PUSLIT IAIN Walisongo.

Hanani, D. (2014). Pendidikan karakter anak menurut Imam Al-Ghazali. Jurnal Pembaharuan Pendidikan Islam (JPPI), 1(1).

Janna, S. R. (2013). Konsep Pendidikan Anak dalam Perspektif Al-ghazali (Implikasinya dalam Pendidikan Agama Islam). Al-Ta'dib, 6(2), 41-55.

Kosim, M. (2012). Urgensi Pendidikan Karakter. KARSA: Journal of Social and Islamic Culture, 19(1), 84-92.

Kusumawati, Intan. (2017). Pengembangan Karakter Siswa Raudlatul Athfal Berbasis Pendidikan Agama Islam. As- ibyān: Jurnal Pendidikan Anak Usia Dini, 1(02), 139148.

Kusumawati, Intan. (2019). Pendidikan Moral Anak Usia Dini Melalui Pendekatan Konstruktivis. Jurnal Fakultas Keguruan dan Ilmu Pendidikan Universitas Cokroaminoto Yogyakarta, 10(01).

Lickona, T. (1991). Educating for character: How our school can teach respect and responsibility. New York: Bantam Books.

Mulyasa, H.E. (2013). Manajemen Pendidikan Karakter. Jakarta: Bumi Aksara. Sekolah. Bandung: Remaja Rosdakarya.

Republik Indonesia. (2003). Undang-Undang RI Nomor 20 Tahun 2003, tentang Sistem Pendidikan Nasional.

Setiawan, A. (2014). Prinsip Pendidikan Karakter dalam Islam. Dinamika Ilmu, 14, (1), 9.

Sudaryanti. (2012). Pentingnya Pendidikan Karakter Bagi Anak Usia Dini. Jurnal Pendidikan Anak, 1, (1), 12-13.

Sugiyono. (2009). Metode Penelitian Kuantitatif, Kualitatif dan R\&D, Bandung : Alfabeta.

Tilaar, H.A.R. (1999). Pendidikan, Kebudayaan, dan Masyarakat Madani Indonesia. Editor: Mukhlis. Bandung: Remaja Rosdakarya. 